\title{
How Institutional Distance and International Experience Affect the Success or Failure of Foreign Direct Investment by Chinese Enterprises?
}

\author{
Jiao Yang \\ School of Economics, Jinan University, Guangzhou, China \\ Email: 13129368192@163.com
}

How to cite this paper: Yang, J. (2019) How Institutional Distance and International Experience Affect the Success or Failure of Foreign Direct Investment by Chinese Enterprises? American Journal of Industrial and Business Management, 9, 512-535.

https://doi.org/10.4236/ajibm.2019.93035

Received: February 15, 2019

Accepted: March 15, 2019

Published: March 18, 2019

Copyright $\odot 2019$ by author(s) and Scientific Research Publishing Inc. This work is licensed under the Creative Commons Attribution International License (CC BY 4.0).

http://creativecommons.org/licenses/by/4.0/

\begin{abstract}
With the sample of 2571 foreign direct investment of multinational enterprises in China from 2005 to 2016, the Logit model is used in this paper to empirically test the influence of host country system differences and international experience on the success or failure of foreign direct investment by Chinese enterprises. Our empirical findings are: the greater the difference in institutional distance (whether positive or negative), the larger the possibility that foreign direct investment by Chinese enterprises will fail, that is, the institutional distance is featured by "symmetric effect" on the success or failure of foreign direct investment by Chinese enterprises; as a "distance bridging" variable, international experience has regulatory effect that weakens the negative effect of institutional distance on Chinese enterprises' overseas direct investment success rate in the negative institutional distance, but has no regulating effect in the positive institutional distance, which is featured by "asymmetric effect"; the adjustment of institutional distance to the success or failure of foreign direct investment by Chinese enterprises has industry characteristics. When Chinese enterprises directly invest in "sensitive" industries, the adjustment effect of international experience on the relationship between negative institutional distance and investment success or failure is less obvious than that in "non-sensitive" industries. In addition, the sample data of foreign investment by China's multinational corporation in the "Belt and Road" countries are examined, which is consistent with conclusions. The research results also show that the host country's dependence on trade, infrastructure and strategic resources are all important factors affecting the success or failure of foreign direct investment of Chinese multinational enterprises. According to the above conclusions, some suggestions and countermeasures are proposed in this paper.
\end{abstract}




\section{Keywords}

Success or Failure of Foreign Direct Investment, Institutional Distance, International Experience

\section{Introduction}

Under the guidance of the "going out" strategy and the advocacy of the "One Belt, One Road" cooperative development concept, foreign direct investment by Chinese enterprise has developed rapidly. According to 2016 Statistical Bulletin of China's Foreign Direct Investment, China's foreign direct investment flows reached a record high of US $\$ 196.15$ billion in 2016, with a year-on-year increase of $34.7 \%$, accounting for $13.5 \%$ of the global total. However, compared with China's booming OFDI situation, another reality is that Chinese companies' overseas mergers and acquisitions mostly ended in failure. For example, CNOOC's acquisition of American oil company Unocal failed due to a strong political rebound, holding increase of Australia Rio's operations by Chinalco failed due to political system resistance, and a large number of Chinese companies stopped working due to Libya's riots. In fact, even those deals that have been successfully completed have a tortuous experience behind themselves. The system theory holds that the institutional factor, as the basis of influencing the enterprise behavior [1], gradually forms the system basis view. According to many practical cases and related research, institutional barriers have become the primary problem faced by going out of multinational corporations. Scholars also generally believe that institutional factors are increasingly becoming the key to understanding and analyzing the behavior of multinational corporations. Therefore, this paper studies the impact of the host country and China's institutional distance on the success or failure of foreign direct investment by Chinese multinational corporations. This helps us to understand more deeply the problems that our enterprises may face in transnational operation, and also helps our multinational enterprises to go out better and faster.

Most of the current research is still at the institutional quality level of the host country or home country, and a few studies focus on the system differences between the host country and the home country; moreover, it mainly studies the impact of the host country system's quality and differences with the home country system on flows and risks of foreign direct investment, and does not study the success or failure of foreign direct investment; at the same time, scholars are concerned about the impact of the institutional distance between home and host countries on OFDI, but do not distinguish the directivity of institutional distance (i.e., the positive institutional distance that the host country is cleaner than China and the negative institutional distance that the host country is less clean than China). Therefore, this paper studies the impact of institutional differences and international experience on the success or failure of foreign direct invest- 
ment by Chinese enterprises using the data of Chinese multinationals from 2005 to 2016. At the same time, the above analysis will also be conducted on the samples of the countries along the "Belt and Road". The research has regional characteristics, with conclusions that have certain guiding significance for Chinese enterprises to make foreign investment in the countries along the "Belt and Road" in the future.

\section{Literature Review and Theoretical Assumptions}

\subsection{Literature Review}

To begin with, from the perspective of the host country system, after systematical summary the relevant literature on the host country system and foreign direct investment, The scholar believed that the mechanism of the host country system for FDI was mainly embodied in the following contents: First, the deprivation of investor assets can be easily caused due to the poor institutional environment. For instance, local government with opportunistic motives may illegally encroach on investor assets because of the imperfection and absence of the property right system, which thereby reduces the foreigners' investment willingness; second, the defects of the system that regulate market operations will increase investment costs. For instance, problems such as rent-seeking and corruption increase the investment cost of enterprises, which thereby constrains the occurrence of investment behaviors; third, institutional defects often lead to low quality of public goods provided by governments (such as the judicial system, government efficiency and regulation, etc.), thus affecting the expected return on investment [2]. The scholars found that institutional quality is significantly positively correlated with FDI, and FDI is more inclined to superior institutional environment [3] [4] [5]. However, the above conclusion is not supported by all studies, Conversely, some scholars found that China's OFDI is better than that in the regions and countries with high political risks and poor institutional quality [6] [7] [8]. It can be seen that there are many indicators reflecting the system and different quantitative methods of institutional indicators. Due to the different institutional indicators and data sources, a lot of inconsistent conclusions are obtained in the empirical research on the effect of the system on FDI.

What's more, they can be analyzed from the perspective of the distance between the host country system and the multinational enterprise system. System quality is an absolute evaluation of the host country system, with universal impact on the OFDI of various countries. As the degree of similarity or dissimilarity between the two countries' regulation, cognitive and normative systems [9], system distance is a relative evaluation of the host country and the home country, with a specific impact on the OFDI of a particular home country. In studying foreign direct investment decisions, we should not only consider the institutional quality and environment of the host country, but also the relative institutional quality and environment of the host country and the home country [10]. According to the study, the absolute differences in bilateral systems are nega- 
tively correlated with FDI [10] [11], which are verified by scholars using China's data [12] [13] [14]. In contrast, the scholars found that the OFDI of Chinese enterprises is positively related to the bilateral system distance [15]. In addition, some scholars hold a two-fold attitude. For instance, the scholars found through empirical research: Companies that implement a global integration strategy tend to choose a host country with a smaller distance from the normative and cognitive systems of home country, while companies that implement a multinational localization strategy choose a host country that has a larger normative and cognitive institutional distance from the home country [16]. The scholar believed that: if the host country's formal institutional environment is excellent, it will attract Chinese capital inflows better, while the informal institutional distance hinders Chinese enterprises OFDI.

According to above domestic and foreign literature, most of the current research is still at the institutional quality level of the host country or home country, and a few studies focus on the system differences between the host country and the home country; moreover, it mainly studies the impact of the host country system's quality and differences with the home country system on flows and risks of foreign direct investment, and does not study the success or failure of foreign direct investment; at the same time, scholars are concerned about the impact of the institutional distance between home and host countries on OFDI, but do not distinguish the directivity of institutional distance (i.e., the positive institutional distance that the host country is cleaner than China and the negative institutional distance that the host country is less clean than China). Therefore, this paper studies the impact of institutional differences and international experience on the success or failure of foreign direct investment by Chinese enterprises using the data of Chinese multinationals from 2005 to 2016. At the same time, the above analysis will also be conducted on the samples of the countries along the "Belt and Road". The research has regional characteristics, with conclusions that have certain guiding significance for Chinese enterprises to make foreign investment in the countries along the "Belt and Road" in the future.

\subsection{Theoretical Assumptions}

1) Difference of Institution

In a general sense, the greater the institutional gap between the home country and the host country, the more difficult it is for multinational companies to apply the strategic practices of their parent companies to their subsidiaries in the host country. When multinational corporations make direct foreign investment to the host country with a large gap with the home country system, they not only need to face the risks arising from differences in regulatory regimes such as judicial dispute resolution mechanism and contract guarantee, but also overcome differences of normative systems between home and host countries such as cultural backgrounds and social norms. On the one hand, due to the these institu- 
tional distances multinational company investors need to spend more time and energy to familiarize themselves with the host country market and search for local market and interpersonal behavior information, and require to pay additional costs associated with communication and negotiation, contract performance guarantee, etc., which undoubtedly increases the risk of foreign direct investment; on the other hand, in order to carry out its business operations more effectively, a multinational company must abide by certain rules and regulations to obtain internal and external legitimacy in the host country when entering the host country. The institutional distance brings different levels of internal and external legitimacy acquisition barriers, and raises the threshold for the legitimacy acquisition of multinational corporations [17]. So we make the following assumptions:

Assumption 1: In a country with a positive institutional distance, the greater the institutional distance, the larger the possibility that the Chinese foreign direct investment will fail.

Assumption 2: In a country with a negative institutional distance, the greater the institutional distance, the larger the possibility that the Chinese foreign direct investment will fail.

2) International Experience

Experience is an intangible asset that constitutes the advantage of the organization competition [18]. According to the traditional experience learning curve effect, the more frequently a task is executed, the less the cost of completing it, the better the implementation effect. In order to avoid losses and obtain maximum benefits, investment companies often provide experience for follow-up investment through pre-investment. Empirical knowledge minimizes uncertainty for companies to the full extent [19]. And the investment experience is the only way to obtain this empirical knowledge, with no obvious alternatives [20]. With the increase of accumulated experience of multinationals, the impact of institutional distance is diminished. It can be seen that distance reduces similarity, while experience increases similarity, and international experience can make "bridge" for distance. However, if the system of the host country is perfect, the property rights are protected, the contract is executed effectively, the supervision is in place, the system is transparent, and the officials are clean, the operational uncertainty and risks of the multinational companies will be reduced, thus obtaining the system dividend. The investment of Chinese enterprises in the country with a positive system can obtain a certain institutional dividend and helps to reduce the investment risk, thus reducing the adjustment effect of international experience on the relationship between the institutional distance and the success or failure of Chinese enterprises' foreign direct investment. So we make the following assumptions:

Assumption 3: International experience can directly increase the success rate of foreign direct investment by Chinese enterprises.

Assumption 4: Under the established positive institutional distance, the success rate of foreign direct investment of enterprises with international experience 
cannot be higher than that of other enterprises in the past.

Assumption 5: Under the established negative institutional distance, the success rate of foreign direct investment of enterprises with international experience can be higher than that of other enterprises in the past.

According to statistics, the failure rate of Chinese enterprises in the "sensitive" industries such as energy, transportation and high-tech has been high in the past decade, which reflects the success or failure of foreign direct investment of Chinese multinational enterprises has obvious industry characteristics. The direct investment of Chinese enterprises in these "sensitive" industries can threaten the host country's national interests and political security, and touch the local government's "red line of consciousness", and cause its vigilance and direct or indirect obstruction [12], which, therefore, increases the risk of foreign direct investment of Chinese enterprises and makes foreign direct investment more likely to fail. Therefore, when Chinese enterprises directly invest in "sensitive" industries, the adjustment effect of international experience on the relationship between negative institutional distance and investment success rate is not obvious for that of investment in the "non-sensitive" industries. We propose the following assumptions:

Assumption 6: When Chinese enterprises directly invest in "non-sensitive" industries, the adjustment effect of international experience on the relationship between negative institutional distance and investment success rate is greater than that of investment in "non-sensitive" industries.

In recent years, Chinese enterprises have accelerated the "steps of going out" with the advancement of the "Belt and Road" international cooperation. In 2015-2016, China's foreign direct investment flows in the countries along the "Belt and Road" reached US\$18.9 billion and US\$129.41 billion, respectively, with good growth momentum and broad development prospects. However, the "Belt and Road" involves many countries in Europe and Asia. With large differences in systems and frequent political changes, these countries are not only high-corruption zone and high political risk path, but also regions with a low level of rule [8]. Chinese enterprises have greater risks in direct investment in these countries, but, at the same time, the investment risks of countries along the "Belt and Road" can be reduced with the continuous accumulation of "going out" international experience. According to the previous theory, we propose the following assumptions:

Assumption 7: The success rate of foreign direct investment by enterprises with international experience in the past in the country with positive institutional distance along the belt and road route will not be higher than that of other enterprises.

Assumption 8: The success rate of foreign direct investment by enterprises with international experience in the past in the country with negative institutional distance along the belt and road route will not be higher than that of other enterprises. 


\section{Model Settings and Variables, Data Description}

\subsection{Model Setting}

Combined with the theoretical mechanism of literature review, the following measurement model is constructed to achieve the purpose of this paper:

$$
\begin{aligned}
& \left.\operatorname{Logit}_{\left(\text {suc }_{i j, t}\right)}\right)=\alpha+\beta_{1} \text { Dist_insti }_{i j, t}+\beta_{2} \text { Dist_instiP }_{i j, t}+\beta_{3} \text { Dist_instiN } N_{i j, t} \\
& +\beta_{4} E X P_{i j, t}+\eta X_{i j, t}+\varepsilon_{i j, t} \\
& \left.\operatorname{Logit}_{\left(\text {suc }_{i j, t}\right)}\right) \alpha+\beta_{1} \text { Dist_insti }_{i j, t}+\beta_{2} \text { Dist_instiP }_{i j, t}+\beta_{3} \text { Dist_instiN }_{i j, t} \\
& +\beta_{4} E X P_{i j, t}+\beta_{5} \text { Dist_insti }_{i j, t} * E X P_{i j, t}+\beta_{6} \text { Dist_instiP }_{i j, t} * E X P_{i j, t} \\
& +\beta_{7} \text { Dist_insti }_{i j, t} * E X P_{i j, t}+\eta X_{i j, t}+\varepsilon_{i j, t}
\end{aligned}
$$

The dependent variable $s u c_{i j, t}$ is a binary dummy variable. When Chinese multinational corporations $i$ enter the country $j$ and make successful foreign direct investment during the period $t, s u c_{i j, t}=1$; when foreign direct investment fails, $s u c_{i j, t}=0 ;$ Dist_instiP $P_{i j, t}$ indicates the absolute value of the positive institutional distance, Dist_instiN $N_{i j, t}$ indicates the absolute value of the negative institutional distance, Dist_insti $i_{i j, t}$ indicates the absolute value of the institutional distance. $E X P_{i j, t}$ indicates international experience, $X_{i j, t}$ is control variable, $\varepsilon_{i j, t}$ indicates random error term.

\subsection{Variables and Data Description}

1) Dependent variable: The dependent variable $s u c_{i j, t}$ is a binary dummy variable. When Chinese multinational corporations $i$ enter the country $j$ and make successful foreign direct investment during the period $t, s u c_{i j, t}=1$; when foreign direct investment fails, $s u c_{i j, t}=0$;

2) Independent variables:

a) With regard to institutional indicators, this paper draws on the practices of the scholars [21] [22] and weighs them using the World Health Governance Indicators (WGI) developed by the World Bank, including voice and accountability, political stability, government effectiveness, regulatory quality, rule of law, and corruption control.

These six sub-indicators are standardized, with values between -2.5 and 2.5 . The larger the value, the better the state of relevant government governance. WGI is more comprehensive than other indicators, which has been used most frequently in cross-country research involving institutional factors in recent years. At the same time, according to the practices of the scholars [10] [23], comprehensive indicator score of the quality of the host country system is obtained using factor analysis and principal component factor analysis. The difference between the score of the comprehensive index of the host country system and that of China is used to indicate the absolute value of the positive institutional distance. The difference between the scores of the comprehensive index of institutions in China and that of the host country system is used to indicate the 
absolute value of the negative institutional distance.

b) International experience, as this variable indicates, before the period $t$, if the enterprise has investment experience in the same or similar market, the value will be 1 , and if no investment experience, it will be recorded as 0 .

3) Control variables:

a) The economy size of the host country (lngdp), representing the market size of the host country, is measured by the natural logarithm of GDP (the constant US dollar in 2010), and the data comes from the World Bank database.

b) Trade dependence (lntrade), measured by the natural logarithm of the host country's total trade as a percentage of GDP in the current year, obtains data from the World Bank database.

c) The natural resource endowment (Raw) of the host country, in percentage, selects the percentage of fuel exports and ores and metals exports to exports commodity to represent the abundance of natural resources in the host country, and obtains data from the World Bank database.

d) Host country infrastructure (Internet users per 100 people, or Inter for short) selects the Internet users per 100 people (Inter) to represent the infrastructure level of the host country, and its data comes from the World Bank database.

e) The host country's strategic resource endowment (High-technology, referred to as Tech) is measured by the percentage of high-tech exports to manufactured exports, and its data comes from the World Bank database

f) Host country labor endowment (Rural population, referred to as Ruralp). The proportion of rural population to the total population is used to represent the labor endowment of the host country in this paper, and its data comes from the World Bank database.

g) local currency exchange rate (lnrate), combined with the practices of the scholars [24], is measured by the natural logarithm of the AMA exchange rate. It is the exchange rate obtained by United Nations Statistics Office from appropriate adjustments of the annual average exchange rate and price adjustment exchange rate of the International Monetary Fund. And its data is from the United Nations Commodity Trade Statistics Database.

h) Geographic distance (lndist) takes the natural logarithm of trade distance between China and the host country to represent the iceberg cost of the company's foreign direct investment. The data comes from the CEPII database, which provides bilateral distances measured in four different ways, covering 225 countries. This paper uses the third set of measurements, which is obtained from the weight calculation according to the proportion of the main population gathering place distance to total population it accounts for.

i) Sensitivity of the investee industry (sector), the direct investment of Chinese enterprises in these "sensitive" industries can threaten the host country's national interests and political security, and touch the local government's "red line of consciousness", and cause its vigilance and direct or indirect obstruction, which, 
therefore, increases the risk of foreign direct investment of Chinese enterprises and makes foreign direct investment more likely to fail. Sector $=1$ means that the invested party is engaged in "sensitive" industries such as energy, transportation and high technology. Conversely it is equal to 0 .

The statistical description of each variable is shown in Table 1. In the case of data loss is not serious, in order to maintain the sample capacity, the "linear interpolation" method can be used to fill in the missing data. In the case of complete data loss, it is completely ignored.

\section{Empirical Test and Result Analysis}

\subsection{Institutional Distance and the Success or Failure of Foreign Direct Investment by Chinese Enterprises}

Due to the very high correlation coefficient between the positive and negative institutional distances, they are separately substituted into the model during regression analysis, so as to avoid multi-collinearity between variables. According to the analysis in the theoretical assumption part, the difference in bilateral systems increases the possibility of failure of foreign direct investment by Chinese enterprises. In order to verify the theoretical hypothesis, the model (1) is used in his paper to test the impact of bilateral institutional differences on the success or failure of foreign direct investment by Chinese enterprises, as shown in Table 2. The Wald test and LR test of each model are significant at the level of $1 \%$, indicating that the overall interpretation ability of each model is strong. The positive institutional distance coefficient is significantly negative, indicating that the greater the difference in the positive institutional distance, the larger the possibility that the Chinese foreign direct investment will fail, which is consistent with the previous consumption 1 . The sign of the distance coefficient of the negative system is significantly negative, indicating that the greater the difference in the distance from the negative system, the larger the possibility that the Chinese foreign direct investment will fail, which is consistent with the previous hypothesis 2 . From the above conclusions, it can be seen that moderate institutional differences can increase the success possibility of foreign direct investment of Chinese enterprises. Why can moderate institutional difference increase the possibility of successful foreign direct investment of Chinese enterprises? As a developing country that is undergoing transformation, China faces the institutional problems that exist in other developing countries. Due to the "various institutional defects" existing in China, Chinese enterprises use various "techniques" and "relationships" to solve institutional obstacles. Therefore, familiar "non-market skills" may be used by Chinese companies to dredge the host country rules in a harsh institutional environment, and "relationships" is used to replace the formal systems to gain "convenience" in the market [15]. The moral and economic costs of the same behavior become lower in a developing country with similar institutions. Therefore, when the institutional differences are in a moderate range, "non-market skills" may be used by Chinese enterprises to clear institutional 
Table 1. Descriptive statistics for variables.

\begin{tabular}{|c|c|c|c|c|c|}
\hline Variable & $\begin{array}{c}\text { Observation } \\
\text { number }\end{array}$ & Mean & $\begin{array}{l}\text { Standard } \\
\text { deviation }\end{array}$ & $\begin{array}{l}\text { Maximum } \\
\text { value }\end{array}$ & $\begin{array}{l}\text { Minimum } \\
\text { value }\end{array}$ \\
\hline $\begin{array}{l}\text { Success or failure of foreign } \\
\text { direct investment (SUC) }\end{array}$ & 2571 & 0.919 & 0.273 & 0 & 1 \\
\hline $\begin{array}{l}\text { Institutional distance } \\
\text { (Dist_insti) }\end{array}$ & 2571 & 0.650 & 0.477 & 0 & 1 \\
\hline $\begin{array}{l}\text { Positive institutional } \\
\text { distance (Dist_instiP) }\end{array}$ & 1614 & 1.293 & 0.862 & 0.000798 & 2.615 \\
\hline $\begin{array}{l}\text { Negative institutional } \\
\text { distance (Dist_instiN) }\end{array}$ & 957 & 0.499 & 0.329 & 0.00814 & 1.658 \\
\hline $\begin{array}{l}\text { International experience } \\
\text { (EXP) }\end{array}$ & 2571 & 0.884 & 0.321 & 0 & 1 \\
\hline $\begin{array}{l}\text { The economy scale of host } \\
\text { country (lngdp) }\end{array}$ & 2552 & 26.430 & 2.198 & 19.222 & 30.460 \\
\hline Trade dependence (Trade) & 2541 & 73.822 & 57.057 & 0.167 & 441.604 \\
\hline $\begin{array}{l}\text { Natural resource endowment } \\
\text { of host country (Raw) }\end{array}$ & 2416 & 35.363 & 31.612 & 0.081 & 99.791 \\
\hline $\begin{array}{l}\text { Infrastructure of host country } \\
\text { (Referred to as Inter) }\end{array}$ & 2560 & 44.957 & 30.796 & 0 & 97.494 \\
\hline $\begin{array}{l}\text { Strategic resource } \\
\text { endowment of host } \\
\text { country (Tech) }\end{array}$ & 2379 & 12.123 & 12.477 & 0.00003 & 68.900 \\
\hline $\begin{array}{l}\text { Labor endowment of host } \\
\text { country (Ruralp) }\end{array}$ & 2569 & 37.381 & 23.831 & 0 & 139.79 \\
\hline $\begin{array}{l}\text { Exchange rate of local } \\
\text { currency (lnrate) }\end{array}$ & 2571 & 2.827 & 3.071 & -1.543 & 10.339 \\
\hline Sensitive industry (sector) & 2571 & 0.503 & 0.500 & 0 & 1 \\
\hline Geographic distance (lndist) & 2561 & 8.908 & 0.526 & 7.025 & 9.858 \\
\hline
\end{tabular}

barriers, thereby improving the success possibility of foreign direct investment in Chinese enterprises. However, when institutional differences are large enough, such institutional risks may be insurmountable, or it can be overcome at the cost of a lot of money. Therefore, the excessive institutional differences lead to the larger possibility that the foreign direct investment by Chinese enterprises will fail.

From the perspective of control variables, according to the significantly positive infrastructure of the Middle East (Inter) shown in Table 2, the good infrastructure conditions of the host country can reduce the operating costs of enterprises, improve production efficiency, and increase the success rate of foreign direct investment of multinational enterprises in China. According to the mostly positive trade dependence (Trade), the higher the degree of openness of the host country, the larger the possibility that Chinese companies will invest abroad successfully. The exchange rate of the local currency (lnrate) is mostly negative, indicating that the higher the exchange rate of the local currency in the host country (i.e., the lower the foreign exchange rate of China), the larger the renminbi 
Table 2. The marginal utility of international experience on the relationship between institutional distance and the success or failure of foreign direct investment by Chinese enterprises.

\begin{tabular}{|c|c|c|c|c|c|c|}
\hline & \multicolumn{3}{|c|}{ Binary Logit } & \multicolumn{3}{|c|}{ Binary probit } \\
\hline & $\begin{array}{c}\text { No } \\
\text { direction }\end{array}$ & $\begin{array}{l}\text { Positive } \\
\text { distance }\end{array}$ & $\begin{array}{l}\text { Negative } \\
\text { distance }\end{array}$ & $\begin{array}{c}\text { No } \\
\text { direction }\end{array}$ & $\begin{array}{l}\text { Positive } \\
\text { distance }\end{array}$ & $\begin{array}{l}\text { Negative } \\
\text { distance }\end{array}$ \\
\hline Dist_insti & $\begin{array}{c}-0.764^{* * *} \\
(0.155)\end{array}$ & & & $\begin{array}{c}-0.384^{* * *} \\
(0.078)\end{array}$ & & \\
\hline Dist_instiP & & $\begin{array}{c}-0.863^{\star * *} \\
(0.189)\end{array}$ & & & $\begin{array}{c}-0.454^{* * *} \\
(0.096)\end{array}$ & \\
\hline Dist_instiN & & & $\begin{array}{c}-1.652^{\star * *} \\
(0.580)\end{array}$ & & & $\begin{array}{c}-0.850^{* * *} \\
(0.295)\end{array}$ \\
\hline Experienced & $\begin{array}{c}0.648^{* * *} \\
(0.205)\end{array}$ & $\begin{array}{l}0.526^{* *} \\
(0.233)\end{array}$ & $\begin{array}{l}1.066^{* *} \\
(0.468)\end{array}$ & $\begin{array}{c}0.338^{* * *} \\
(0.107)\end{array}$ & $\begin{array}{l}0.279^{* *} \\
(0.122)\end{array}$ & $\begin{array}{l}0.538^{* *} \\
(0.237)\end{array}$ \\
\hline $\operatorname{lngdp}$ & $\begin{array}{l}0.118^{\star} \\
(0.071)\end{array}$ & $\begin{array}{l}0.140^{*} \\
(0.081)\end{array}$ & $\begin{array}{c}0.111 \\
(0.218)\end{array}$ & $\begin{array}{c}0.054 \\
(0.035)\end{array}$ & $\begin{array}{l}0.070^{*} \\
(0.040)\end{array}$ & $\begin{array}{c}0.050 \\
(0.094)\end{array}$ \\
\hline Trade & $\begin{array}{c}0.007^{* * *} \\
(0.002)\end{array}$ & $\begin{array}{c}0.009^{* * *} \\
(0.003)\end{array}$ & $\begin{array}{l}-0.009 \\
(0.008)\end{array}$ & $\begin{array}{c}0.003^{* * *} \\
(0.001)\end{array}$ & $\begin{array}{c}0.004^{* * *} \\
(0.001)\end{array}$ & $\begin{array}{l}-0.004 \\
(0.003)\end{array}$ \\
\hline Raw & $\begin{array}{c}0.000 \\
(0.003)\end{array}$ & $\begin{array}{c}0.007 \\
(0.004)\end{array}$ & $\begin{array}{l}-0.009 \\
(0.007)\end{array}$ & $\begin{array}{c}0.000 \\
(0.002)\end{array}$ & $\begin{array}{l}0.004^{*} \\
(0.002)\end{array}$ & $\begin{array}{l}-0.004 \\
(0.003)\end{array}$ \\
\hline Inter & $\begin{array}{c}0.021^{* * *} \\
(0.006)\end{array}$ & $\begin{array}{c}0.021^{* * *} \\
(0.007)\end{array}$ & $\begin{array}{l}0.020^{*} \\
(0.011)\end{array}$ & $\begin{array}{c}0.010^{* * *} \\
(0.003)\end{array}$ & $\begin{array}{c}0.011^{* * *} \\
(0.004)\end{array}$ & $\begin{array}{l}0.010^{*} \\
(0.005)\end{array}$ \\
\hline Tech & $\begin{array}{c}-0.022^{* *} \\
(0.010)\end{array}$ & $\begin{array}{l}-0.014 \\
(0.012)\end{array}$ & $\begin{array}{c}-0.058^{* * *} \\
(0.019)\end{array}$ & $\begin{array}{c}-0.010^{* *} \\
(0.005)\end{array}$ & $\begin{array}{l}-0.005 \\
(0.006)\end{array}$ & $\begin{array}{c}-0.032^{* * *} \\
(0.010)\end{array}$ \\
\hline Ruralp & $\begin{array}{c}0.022^{* * *} \\
(0.008)\end{array}$ & $\begin{array}{l}0.022^{\star *} \\
(0.010)\end{array}$ & $\begin{array}{c}0.012 \\
(0.015)\end{array}$ & $\begin{array}{l}0.010^{\star *} \\
(0.004)\end{array}$ & $\begin{array}{l}0.010^{* *} \\
(0.005)\end{array}$ & $\begin{array}{c}0.005 \\
(0.007)\end{array}$ \\
\hline lnrate & $\begin{array}{l}-0.028 \\
(0.043)\end{array}$ & $\begin{array}{l}-0.068 \\
(0.050)\end{array}$ & $\begin{array}{c}0.091 \\
(0.072)\end{array}$ & $\begin{array}{c}--0.018 \\
(0.020)\end{array}$ & $\begin{array}{l}-0.035 \\
(0.026)\end{array}$ & $\begin{array}{c}0.036 \\
(0.034)\end{array}$ \\
\hline lndist & $\begin{array}{c}0.088 \\
(0.189)\end{array}$ & $\begin{array}{c}0.158 \\
(0.235)\end{array}$ & $\begin{array}{c}0.448 \\
(0.459)\end{array}$ & $\begin{array}{c}0.046 \\
(0.096)\end{array}$ & $\begin{array}{c}0.090 \\
(0.125)\end{array}$ & $\begin{array}{c}0.181 \\
(0.221)\end{array}$ \\
\hline Sector 2 & $\begin{array}{c}-0.573^{* * *} \\
(0.165)\end{array}$ & $\begin{array}{c}-0.668^{* * *} \\
(0.192)\end{array}$ & $\begin{array}{l}-0.493 \\
(0.328)\end{array}$ & $\begin{array}{c}-0.282^{* * *} \\
(0.082)\end{array}$ & $\begin{array}{c}-0.331^{* * *} \\
(0.097)\end{array}$ & $\begin{array}{l}-0.251 \\
(0.161)\end{array}$ \\
\hline _cons & $\begin{array}{l}-2.237 \\
(3.021)\end{array}$ & $\begin{array}{l}-3.682 \\
(3.451)\end{array}$ & $\begin{array}{l}-3.094 \\
(9.239)\end{array}$ & $\begin{array}{l}-0.763 \\
(1.485)\end{array}$ & $\begin{array}{l}-1.788 \\
(1.765)\end{array}$ & $\begin{array}{l}-0.820 \\
(4.103)\end{array}$ \\
\hline Sample size & 2352 & 1611 & 741 & 2352 & 1611 & 741 \\
\hline Wald $\chi^{2}$ & $62.25^{\star * *}$ & $59.11^{\star * *}$ & $35.48^{* * *}$ & $58.78^{\star * *}$ & $58.70^{* * *}$ & $30.87^{\star * *}$ \\
\hline $\begin{array}{l}\text { Loglike- } \\
\text { ly-hood }\end{array}$ & -625.626 & -448.122 & -163.038 & -626.472 & -448.268 & -163.411 \\
\hline $\operatorname{LR} \chi^{2}$ & $73.900^{* * *}$ & $59.95^{\star * *}$ & $40.07^{\star * *}$ & $72.21^{\star * *}$ & $59.66^{* * *}$ & $39.32^{\star * *}$ \\
\hline
\end{tabular}

Note: The values in parentheses are clustering robust standard errors, ${ }^{*}{ }^{* *}$, and ${ }^{* * *}$ indicate it is significant in the significant levels at $10 \%, 5 \%$, and $1 \%$, respectively.

depreciation, the greater the cost of foreign direct investment of multinational corporations in China, and therefore the greater the possibility of failure. Since most of the host country's strategic resource endowments (Tech) are significantly negative, indicating that our foreign direct investment of multinational corporations that seek high-tech resources is more likely to fail. In recent years, most of China's foreign investment has been concentrated in countries and regions with smaller markets such as Asia and Latin America. A large part of the motivation for "going out" is to seek overseas natural resources. China's multinational corporations have weaker high-tech competitiveness, which makes failure risk is relatively high. Most of the host country's labor endowment (Ruralp) is sig- 
nificantly positive. Faced with the increasing labor costs in the country this year, the host country's abundant cheap labor resources have become an important factor for Chinese companies to "go out" to reduce corporate costs. Most of the sectors of the investee industry are significantly negative, indicating that the success or failure of foreign direct investment in China's multinational corporations has obvious industry characteristics, and foreign direct investment in the "sensitive" industries is more likely to fail. That is because the direct investment of Chinese enterprises in these "sensitive" industries can threaten the host country's national interests and political security, and touch the local government's "red line of consciousness", and cause its vigilance and direct or indirect obstruction, which, therefore, increases the risk of foreign direct investment of Chinese enterprises and makes foreign direct investment more likely to fail.

\subsection{The Regulating Effect of International Experience on the Relationship between Institutional Distance and the Success or Failure of Foreign Direct Investment by Chinese Enterprises}

Combined with the previous theoretical assumptions, the model (2) is used to test the adjustment effect of international experience on the relationship between institutional distance and the success or failure of foreign direct investment by Chinese enterprises. See Table 3 for details. Both Wald test and LR test of each model are significant at the level of $1 \%$, indicating that the overall explanatory ability of each model is strong. Interacting items of international experience and institutional distance are added to each model. In order to overcome the multicollinearity problem caused by multiplication of variables, the institutional distance and international empirical variables are processed by centralized treatment in this article. And the variance expansion factor after processing is greatly reduced, which is lower than the critical value of 10. From the regression results of the following three models, according to significantly positive coefficients of international experience, international experience can directly improve the success rate of foreign direct investment of Chinese enterprises, which strongly support assumption 3 . When Chinese enterprises directly invest in the country with positive institutional distance, although the coefficient of the positive system distance itself is significantly negative, the coefficient of the interaction between the positive institutional distance and the international experience is no longer significant. This shows that international experience does not weaken the regulatory effect of positive institutional distance on the negative impact of success rate overseas direct investment of Chinese enterprises, and the result strongly supports assumption 4 . This is because Chinese enterprises can obtain a certain system dividend by investing in a positive system, which helps to reduce investment risks, thereby reducing the adjustment effect of international experience on the relationship between institutional distance and the success or failure of foreign direct investment by Chinese enterprises. When Chinese enterprises 
Table 3. The regulating effect of international experience on the relationship between institutional distance and the success or failure of foreign direct investment by Chinese enterprises.

\begin{tabular}{|c|c|c|c|c|c|c|}
\hline & \multicolumn{3}{|c|}{ Binary Logit } & \multicolumn{3}{|c|}{ Binary Probit } \\
\hline & $\begin{array}{c}\text { No } \\
\text { direction }\end{array}$ & $\begin{array}{l}\text { Positive } \\
\text { distance }\end{array}$ & $\begin{array}{l}\text { Negative } \\
\text { distance }\end{array}$ & $\begin{array}{c}\text { No } \\
\text { direction }\end{array}$ & $\begin{array}{l}\text { Positive } \\
\text { distance }\end{array}$ & $\begin{array}{l}\text { Negative } \\
\text { distance }\end{array}$ \\
\hline \multirow{2}{*}{ Dist_instiEXP } & -0.196 & -0.178 & $3.771^{\star}$ & -0.083 & -0.081 & $2.307^{\star \star}$ \\
\hline & $(0.234)$ & $(0.305)$ & $(1.947)$ & $(0.124)$ & $(0.159)$ & $(1.000)$ \\
\hline \multirow{2}{*}{ Dist_insti } & $-0.774^{\star * \star}$ & $-0.871^{\star * *}$ & $-1.796^{* * *}$ & $-0.386^{* * *}$ & $-0.457^{* * *}$ & $-0.955^{\star * *}$ \\
\hline & $(0.156)$ & $(0.189)$ & $(0.623)$ & $(0.078)$ & $(0.096)$ & $(0.311)$ \\
\hline \multirow{2}{*}{ Experienced } & $0.733^{* * *}$ & $0.644^{\star *}$ & $2.946^{* *}$ & $0.370^{* * *}$ & $0.329^{* *}$ & $1.723^{* * *}$ \\
\hline & $(0.224)$ & $(0.306)$ & $(1.161)$ & $(0.116)$ & $(0.156)$ & $(0.608)$ \\
\hline \multirow{2}{*}{ lngdp } & $0.118^{*}$ & $0.140^{*}$ & 0.100 & 0.054 & $0.070^{*}$ & 0.048 \\
\hline & $(0.072)$ & $(0.081)$ & $(0.217)$ & $(0.035)$ & $(0.040)$ & $(0.093)$ \\
\hline \multirow{2}{*}{ Trade } & $0.007^{\star * *}$ & $0.009^{* * *}$ & -0.009 & $0.003^{* * *}$ & $0.004^{\star * *}$ & -0.004 \\
\hline & $(0.002)$ & $(0.003)$ & $(0.008)$ & $(0.001)$ & $(0.001)$ & $(0.003)$ \\
\hline \multirow{2}{*}{ Raw } & 0.000 & 0.007 & -0.009 & 0.000 & $0.004^{*}$ & -0.004 \\
\hline & $(0.003)$ & $(0.004)$ & $(0.007)$ & $(0.002)$ & $(0.002)$ & $(0.003)$ \\
\hline \multirow{2}{*}{ Inter } & $0.021^{\star * *}$ & $0.021^{\star * *}$ & $0.019^{*}$ & $0.010^{* * *}$ & $0.011^{\star * *}$ & $0.010^{*}$ \\
\hline & $(0.007)$ & $(0.007)$ & $(0.011)$ & $(0.003)$ & $(0.004)$ & $(0.005)$ \\
\hline \multirow{2}{*}{ Tech } & $-0.022^{\star *}$ & -0.014 & $-0.056^{\star * *}$ & $-0.010^{\star *}$ & -0.005 & $-0.031^{\star * *}$ \\
\hline & $(0.010)$ & $(0.012)$ & $(0.020)$ & $(0.005)$ & $(0.006)$ & $(0.010)$ \\
\hline \multirow{2}{*}{ Ruralp } & $0.022^{* * *}$ & $0.022^{* *}$ & 0.012 & $0.010^{* *}$ & $0.010^{* *}$ & 0.005 \\
\hline & $(0.008)$ & $(0.010)$ & $(0.015)$ & $(0.004)$ & $(0.005)$ & $(0.007)$ \\
\hline \multirow{2}{*}{ lnrate } & -0.029 & -0.069 & 0.088 & -0.018 & -0.035 & 0.035 \\
\hline & $(0.043)$ & $(0.050)$ & $(0.074)$ & $(0.020)$ & $(0.026)$ & $(0.034)$ \\
\hline \multirow{2}{*}{ lndist } & 0.083 & 0.155 & 0.542 & 0.044 & 0.090 & 0.222 \\
\hline & $(0.190)$ & $(0.237)$ & $(0.473)$ & $(0.096)$ & $(0.125)$ & $(0.223)$ \\
\hline \multirow{2}{*}{ Sector } & $-0.569^{* * *}$ & $-0.668^{* * *}$ & -0.477 & $-0.281^{* * *}$ & $-0.331^{\star \star \star}$ & -0.243 \\
\hline & $(0.165)$ & $(0.192)$ & $(0.332)$ & $(0.082)$ & $(0.097)$ & $(0.161)$ \\
\hline \multirow{2}{*}{ _cons } & -2.860 & -4.229 & -6.163 & -1.081 & -2.081 & -2.580 \\
\hline & $(3.036)$ & $(3.451)$ & $(9.360)$ & (1.493) & $(1.766)$ & $(4.141)$ \\
\hline Sample size & 2352 & 1611 & 741 & 2352 & 1611 & 741 \\
\hline Wald $\chi^{2}$ & $61.32^{\star * *}$ & $58.68^{\star * *}$ & $36.22^{* * *}$ & $58.06^{\star * *}$ & $58.05^{\star * *}$ & $34.85^{\star * *}$ \\
\hline Loglikely-hood & -625.288 & -447.947 & -160.847 & -626.252 & -448.134 & -160.747 \\
\hline $\operatorname{LR} \chi^{2}$ & $74.58^{* * *}$ & $60.30^{* * *}$ & $44.45^{\star * *}$ & $72.65^{\star * *}$ & $59.93^{* * *}$ & $44.65^{\star * *}$ \\
\hline
\end{tabular}

Note: The values in parentheses are clustering robust standard errors, ${ }^{*},{ }^{* *}$, and ${ }^{* * *}$ indicate it is significant in the significant levels at $10 \%, 5 \%$, and $1 \%$, respectively.

invest in a negative system from a country, the negative institutional distance and the international experience interaction are significant, and the coefficient of the negative institutional distance itself is significantly negative. It shows that when investing in the country with negative institutional distance, the international experience significantly weakens the negative effect of the negative institutional distance on the success rate of overseas direct investment of Chinese enterprises. The result strongly supports hypothesis 5 .

\subsection{The Inspections of Industry Differentiation}

Combined with the previous theoretical assumptions, model (2) is used to test regulating effect of international experience on the relationship between institu- 
tional distance and the success or failure of foreign direct investment by Chinese enterprises after distinguishing sensitive industries and sub-sensitive industries. See Table 4 for details. Both Wald test and LR test of each model are significant, indicating that the overall interpretation ability of each model is strong. When Chinese enterprises directly invest in "sensitive" industries, the cross multiplication term of international experience and negative institutional distance is significant at the level of $10 \%$, and the coefficient of negative institutional distance itself is also significant at the level of $10 \%$. When Chinese enterprises directly invest in "non-sensitive" industries, the cross multiplication term of international experience and negative institutional distance is significant at $5 \%$, and the coefficient of negative institutional distance itself is also significant at $5 \%$. It can be seen that when Chinese enterprises directly invest in "sensitive" industries, the adjustment effect of international experience on the relationship between negative institutional distance and the success or failure of investment is less obvious than that in the "non-sensitive" industry, and the results strongly support the assumption 6.

\subsection{Test of Countries along the "Belt and Road"}

Combined with the previous theoretical hypothesis, model (2) are used to test the adjustment effect of international experience on the relationship between the national institutional distance of countries along the "Belt and Road" and the success or failure of foreign direct investment by Chinese enterprises. See Table 5 for details. Both Wald test and the LR test of each model are significant at the level of $1 \%$, indicating that the overall explanatory ability of each model is strong. When Chinese enterprises directly invest in the country with positive system distance along the "One Belt, One Road", although the coefficient of the interaction term between the positive institutional distance and the international experience is significant, the coefficient of the positive institutional distance itself is no longer significant. This shows that the international experience does not weaken the regulatory effect of the positive institutional distance along the "Belt and Road" on the negative effects of direct investment success rate of Chinese enterprises, and the results strongly support the assumption 7 . This is because Chinese enterprises can obtain a certain system dividend by investing in the countries with the positive system distance along the "one belt, one road". It helps to reduce investment risks, thereby reducing the adjustment effect of international experience on the relationship between institutional distance and the success or failure of foreign direct investment of Chinese enterprises. Among the countries with negative institutional distance along the "Belt and Road", which are invested by Chinese enterprises, the negative institutional distance and the international experience are significant, and the coefficient of the negative institutional distance itself is significantly negative. (The coefficient of the negative system distance itself in the Logit model is significant at the level of $15 \%)$. It shows that when investing in the countries with negative institutional distance 
Table 4. The test with distinction between sensitive industries and non-sensitive industries.

\begin{tabular}{|c|c|c|c|c|c|c|}
\hline & \multicolumn{3}{|c|}{ Sensitive industry } & \multicolumn{3}{|c|}{ Non-sensitive industry } \\
\hline & $\begin{array}{c}\text { No } \\
\text { direction }\end{array}$ & $\begin{array}{l}\text { Positive } \\
\text { distance }\end{array}$ & $\begin{array}{l}\text { Negative } \\
\text { distance }\end{array}$ & $\begin{array}{c}\text { No } \\
\text { direction }\end{array}$ & $\begin{array}{l}\text { Positive } \\
\text { distance }\end{array}$ & $\begin{array}{l}\text { Negative } \\
\text { distance }\end{array}$ \\
\hline \multirow{2}{*}{ Dist_insti ${ }^{\star} \mathrm{EXP}$} & -0.039 & -0.175 & $3.579^{\star}$ & -0.380 & -0.082 & $8.917^{\star *}$ \\
\hline & $(0.307)$ & $(0.395)$ & $(2.006)$ & $(0.355)$ & $(0.464)$ & $(3.851)$ \\
\hline \multirow{2}{*}{ Dist_insti } & $-0.806^{* * *}$ & $-0.945^{* * *}$ & $-1.626^{*}$ & $-0.581^{\star *}$ & -0.243 & $-2.246^{\star *}$ \\
\hline & $(0.201)$ & $(0.264)$ & $(0.845)$ & $(0.285)$ & $(0.276)$ & $(0.998)$ \\
\hline \multirow{2}{*}{ Experienced } & $0.671^{\star *}$ & $0.756^{\star}$ & $2.438^{*}$ & $0.783^{\star *}$ & 0.400 & $7.471^{\star * *}$ \\
\hline & $(0.301)$ & $(0.401)$ & $(1.274)$ & $(0.332)$ & $(0.451)$ & $(2.178)$ \\
\hline \multirow{2}{*}{ lngdp } & 0.103 & 0.090 & -0.003 & 0.145 & 0.144 & 0.141 \\
\hline & $(0.094)$ & $(0.116)$ & $(0.236)$ & $(0.114)$ & $(0.127)$ & $(0.484)$ \\
\hline \multirow{2}{*}{ Trade } & 0.005 & 0.066 & -0.030 & $-0.174^{\star \star}$ & $-0.279^{\star * *}$ & $0.654^{\star \star}$ \\
\hline & $(0.065)$ & $(0.097)$ & $(0.103)$ & $(0.073)$ & $(0.074)$ & $(0.292)$ \\
\hline \multirow{2}{*}{ Raw } & $0.006^{* *}$ & $0.009^{*}$ & $-0.012^{*}$ & $0.008^{* *}$ & $0.010^{* *}$ & 0.000 \\
\hline & $(0.003)$ & $(0.005)$ & $(0.007)$ & $(0.004)$ & $(0.005)$ & $(0.018)$ \\
\hline \multirow{2}{*}{ Inter } & -0.001 & 0.001 & -0.001 & 0.004 & $0.017^{\star *}$ & $-0.032^{\star *}$ \\
\hline & $(0.004)$ & $(0.006)$ & $(0.008)$ & $(0.006)$ & $(0.008)$ & $(0.014)$ \\
\hline \multirow{2}{*}{ Tech } & $0.019^{* *}$ & $0.029^{\star *}$ & 0.015 & 0.014 & -0.006 & $0.072^{\star * *}$ \\
\hline & $(0.009)$ & $(0.012)$ & $(0.016)$ & $(0.014)$ & $(0.014)$ & $(0.027)$ \\
\hline \multirow{2}{*}{ Ruralp } & $-0.027^{\star \star}$ & -0.020 & $-0.060^{* * *}$ & -0.012 & -0.007 & -0.093 \\
\hline & $(0.012)$ & $(0.016)$ & $(0.022)$ & $(0.018)$ & $(0.019)$ & $(0.062)$ \\
\hline \multirow{2}{*}{ lnrate } & $0.020^{*}$ & $0.029^{* *}$ & 0.009 & 0.019 & 0.007 & 0.026 \\
\hline & $(0.011)$ & $(0.013)$ & $(0.017)$ & $(0.014)$ & $(0.015)$ & $(0.038)$ \\
\hline \multirow{2}{*}{ lndist } & -0.062 & -0.064 & -0.039 & 0.022 & -0.067 & $0.560^{* * *}$ \\
\hline & $(0.054)$ & $(0.065)$ & $(0.091)$ & $(0.080)$ & $(0.095)$ & $(0.143)$ \\
\hline \multirow{2}{*}{ _cons } & -1.453 & -4.119 & 4.111 & -3.715 & 0.080 & -34.952 \\
\hline & $(4.273)$ & $(5.330)$ & $(10.079)$ & $(5.131)$ & $(5.647)$ & (22.716) \\
\hline Sample size & 1155 & 720 & 435 & 1197 & 891 & 306 \\
\hline Wald $\chi^{2}$ & $41.35^{\star * *}$ & $35.38^{\star * *}$ & $24.08^{\star *}$ & $31.82^{* * *}$ & $36.13^{* * *}$ & $40.92^{* * *}$ \\
\hline Loglikely-hood & -357.619 & -239.876 & -108.499 & -262.206 & -198.699 & -41.838 \\
\hline $\operatorname{LR} \chi^{2}$ & $42.27^{\star * *}$ & $34.92^{* * *}$ & $21.60^{\star *}$ & $30.87^{\star * *}$ & $31.64^{* * *}$ & $41.90^{* * *}$ \\
\hline
\end{tabular}

Note: The v Note: The values in parentheses are clustering robust standard errors, ${ }^{*},{ }^{* *}$, and ${ }^{* * *}$ indicate it is significant in the significant levels at $10 \%, 5 \%$, and $1 \%$, respectively.

along the "Belt and Road", the international experience significantly weakens the regulation effect of negative institutional distance on the negative effect of direct investment success rate of Chinese enterprises. The result strongly supports the consumption 8 .

\section{Robustness Test}

In the basic regression, the total indicator obtained by factor analysis based on the six-dimensional sub-indicators is taken as the indicator of institution distance. In the robustness test, six system quality sub-dimensions of the authority and accountability, political stability, government efficiency, supervision quality, and legal rules corruption control (cleanliness) are used to measure the institutional distance. See Table 6 for details. According to the regression results, the coefficients of the six institutional distances of language rights and accountability, political stability, government efficiency, regulatory quality, legal rules, and 
Table 5. Test of countries along the "Belt and Road".

\begin{tabular}{|c|c|c|c|c|c|c|}
\hline & \multicolumn{3}{|c|}{ Binary Logit } & \multicolumn{3}{|c|}{ Binary probit } \\
\hline & No direction & $\begin{array}{l}\text { Positive } \\
\text { distance }\end{array}$ & $\begin{array}{l}\text { Negative } \\
\text { distance }\end{array}$ & No direction & $\begin{array}{l}\text { Positive } \\
\text { distance }\end{array}$ & $\begin{array}{l}\text { Negative } \\
\text { distance }\end{array}$ \\
\hline \multirow{2}{*}{ Dist_instiEXP } & $1.481^{\star *}$ & $1.423^{*}$ & $5.614^{*}$ & $0.718^{\star *}$ & $0.706^{\star}$ & $3.325^{\star *}$ \\
\hline & $(0.588)$ & $(0.816)$ & (3.295) & $(0.292)$ & $(0.387)$ & $(1.578)$ \\
\hline \multirow{2}{*}{ Dist_insti } & 0.133 & -0.277 & -1.884 & 0.003 & -0.191 & $-0.943^{\star}$ \\
\hline & $(0.451)$ & $(0.561)$ & (1.168) & $(0.206)$ & $(0.256)$ & $(0.562)$ \\
\hline \multirow{2}{*}{ Experienced } & $1.092^{* *}$ & 0.855 & $3.924^{*}$ & $0.512^{\star *}$ & 0.425 & $2.258^{\star *}$ \\
\hline & $(0.462)$ & $(0.568)$ & $(2.261)$ & $(0.219)$ & $(0.262)$ & $(1.073)$ \\
\hline \multirow{2}{*}{ lngdp } & 0.143 & 0.202 & -0.453 & 0.054 & 0.089 & -0.212 \\
\hline & $(0.149)$ & $(0.147)$ & $(0.336)$ & $(0.067)$ & $(0.070)$ & $(0.154)$ \\
\hline \multirow{2}{*}{ Trade } & $0.007^{\star *}$ & $0.010^{\star *}$ & -0.012 & $0.004^{\star *}$ & $0.005^{\star \star}$ & -0.005 \\
\hline & $(0.004)$ & $(0.005)$ & $(0.010)$ & $(0.002)$ & $(0.002)$ & $(0.005)$ \\
\hline \multirow{2}{*}{ Raw } & 0.008 & $0.021^{* *}$ & 0.007 & 0.003 & $0.010^{* *}$ & 0.003 \\
\hline & $(0.007)$ & $(0.009)$ & $(0.013)$ & $(0.003)$ & $(0.004)$ & $(0.006)$ \\
\hline \multirow{2}{*}{ Inter } & $0.017^{\star}$ & $0.030^{\star \star *}$ & 0.018 & $0.007^{\star}$ & $0.014^{* * *}$ & 0.011 \\
\hline & $(0.009)$ & $(0.010)$ & $(0.017)$ & $(0.004)$ & $(0.005)$ & $(0.008)$ \\
\hline \multirow{2}{*}{ Tech } & $-0.025^{\star *}$ & -0.004 & $-0.073^{\star * *}$ & $-0.011^{\star *}$ & 0.000 & $-0.039^{* * *}$ \\
\hline & $(0.011)$ & $(0.014)$ & $(0.027)$ & $(0.006)$ & $(0.007)$ & $(0.014)$ \\
\hline \multirow{2}{*}{ Ruralp } & 0.022 & 0.025 & -0.013 & 0.009 & 0.011 & -0.004 \\
\hline & $(0.016)$ & $(0.016)$ & $(0.028)$ & $(0.007)$ & $(0.008)$ & $(0.013)$ \\
\hline \multirow{2}{*}{ lnrate } & $-0.107^{\star}$ & -0.002 & -0.134 & $-0.050^{*}$ & 0.004 & -0.065 \\
\hline & $(0.060)$ & $(0.077)$ & $(0.124)$ & $(0.028)$ & $(0.036)$ & $(0.055)$ \\
\hline \multirow{2}{*}{ lndist } & 0.248 & $0.953^{\star *}$ & -0.963 & 0.139 & $0.514^{* *}$ & -0.363 \\
\hline & $(0.392)$ & $(0.432)$ & (1.089) & $(0.187)$ & $(0.214)$ & $(0.472)$ \\
\hline \multirow{2}{*}{ Sector } & $-0.570^{*}$ & -0.450 & -1.168 & $-0.261^{*}$ & -0.217 & $-0.520^{*}$ \\
\hline & $(0.315)$ & $(0.415)$ & $(0.721)$ & $(0.143)$ & $(0.190)$ & $(0.286)$ \\
\hline \multirow{2}{*}{ _cons } & -5.210 & $-14.497^{\star \star *}$ & 23.019 & -1.920 & $-6.989^{* * *}$ & 9.768 \\
\hline & $(5.292)$ & $(5.162)$ & $(16.484)$ & $(2.525)$ & $(2.660)$ & $(7.268)$ \\
\hline Sample size & 1046 & 626 & 420 & 1046 & 626 & 420 \\
\hline Wald $\chi^{2}$ & $34.87^{\star * *}$ & $37.62^{\star * *}$ & $33.09^{* * *}$ & $34.46^{* * *}$ & $39.46^{* * *}$ & $32.98^{\star * *}$ \\
\hline Loglikely-hood & -207.221 & -120.419 & -76.504 & -207.530 & -120.193 & -75.984 \\
\hline $\operatorname{LR} \chi^{2}$ & $33.79^{* * *}$ & $29.05^{\star * *}$ & $25.33^{\star * *}$ & $33.17^{\star * *}$ & $29.50^{\star * *}$ & $26.37^{\star * *}$ \\
\hline
\end{tabular}

Note: The values in parentheses are clustering robust standard errors, ${ }^{*},{ }^{*}$, and ${ }^{* * *}$ indicate it is significant in the significant levels at $10 \%, 5 \%$, and $1 \%$, respectively.

corruption control (cleanliness) are all significantly negative. This shows that the greater the institutional distance between the six sub-dimensions, the larger the failure foreign direct investment of Chinese enterprises, which is consistent with the conclusions drawn from the comprehensive indicators with six dimensions in the basic regression.

Considering the large system differences between developed and developing countries, the samples are divided into developed countries and developing countries to carry out further robustness testing according to the classification method of the 2010 Human Development Report of the United Nations Development Programme (UNDP). Since China is currently a developing country, all developed countries invested directly by China are countries with positive system distance. The specific results are shown in Table 7. The interaction term of negative system distance and the international experience are significant, and 
Table 6. Robustness test of sub-dimension indicators of institutional distance.

\begin{tabular}{|c|c|c|c|c|c|c|}
\hline Explanatory variables & Model (1) & Model (1) & Model (1) & Model (1) & Model (1) & Model (1) \\
\hline VAdist & $\begin{array}{c}-0.489^{* * *} \\
(0.134)\end{array}$ & & & & & \\
\hline PSdist & & $\begin{array}{c}-0.400^{\star * *} \\
(0.138)\end{array}$ & & & & \\
\hline Gedist & & & $\begin{array}{c}-0.603^{\star * *} \\
(0.175)\end{array}$ & & & \\
\hline RQdist & & & & $\begin{array}{c}-0.778^{* * *} \\
(0.158)\end{array}$ & & \\
\hline RLdist & & & & & $\begin{array}{c}-0.620^{* * *} \\
(0.153)\end{array}$ & \\
\hline CRdist & & & & & & $\begin{array}{c}-0.642^{* * *} \\
(0.132)\end{array}$ \\
\hline Experienced & $\begin{array}{c}0.675^{\star * *} \\
(0.205)\end{array}$ & $\begin{array}{c}0.729^{* * *} \\
(0.202)\end{array}$ & $\begin{array}{c}0.691^{\star * *} \\
(0.203)\end{array}$ & $\begin{array}{c}0.668^{\star * *} \\
(0.203)\end{array}$ & $\begin{array}{c}0.662^{* * *} \\
(0.205)\end{array}$ & $\begin{array}{c}0.662^{* * *} \\
(0.206)\end{array}$ \\
\hline lngdp & $\begin{array}{c}0.081 \\
(0.067)\end{array}$ & $\begin{array}{c}0.084 \\
(0.069)\end{array}$ & $\begin{array}{c}0.090 \\
(0.072)\end{array}$ & $\begin{array}{c}0.103 \\
(0.073)\end{array}$ & $\begin{array}{l}0.123^{*} \\
(0.071)\end{array}$ & $\begin{array}{c}0.098 \\
(0.071)\end{array}$ \\
\hline Trade & $\begin{array}{l}0.004^{*} \\
(0.002)\end{array}$ & $\begin{array}{c}0.006^{* * *} \\
(0.002)\end{array}$ & $\begin{array}{c}0.007^{\star * *} \\
(0.002)\end{array}$ & $\begin{array}{c}0.007^{\star * *} \\
(0.002)\end{array}$ & $\begin{array}{c}0.007^{\star * *} \\
(0.002)\end{array}$ & $\begin{array}{c}0.007^{\star * *} \\
(0.002)\end{array}$ \\
\hline Raw & $\begin{array}{l}-0.003 \\
(0.003)\end{array}$ & $\begin{array}{c}0.001 \\
(0.003)\end{array}$ & $\begin{array}{c}0.002 \\
(0.003)\end{array}$ & $\begin{array}{c}0.002 \\
(0.003)\end{array}$ & $\begin{array}{c}0.001 \\
(0.003)\end{array}$ & $\begin{array}{c}0.001 \\
(0.003)\end{array}$ \\
\hline Inter & $\begin{array}{c}0.016^{* * *} \\
(0.006)\end{array}$ & $\begin{array}{l}0.010^{*} \\
(0.005)\end{array}$ & $\begin{array}{l}0.013^{\star *} \\
(0.006)\end{array}$ & $\begin{array}{c}0.019^{* * *} \\
(0.006)\end{array}$ & $\begin{array}{c}0.018^{* * *} \\
(0.006)\end{array}$ & $\begin{array}{c}0.020^{* * *} \\
(0.006)\end{array}$ \\
\hline Tech & $\begin{array}{c}-0.017^{*} \\
(0.009)\end{array}$ & $\begin{array}{c}-0.020^{* *} \\
(0.009)\end{array}$ & $\begin{array}{c}-0.020^{* *} \\
(0.010)\end{array}$ & $\begin{array}{c}-0.020^{* *} \\
(0.010)\end{array}$ & $\begin{array}{c}-0.021^{\star *} \\
(0.010)\end{array}$ & $\begin{array}{c}-0.021^{* *} \\
(0.009)\end{array}$ \\
\hline Ruralp & $\begin{array}{c}0.022^{* * *} \\
(0.008)\end{array}$ & $\begin{array}{c}0.024^{* * *} \\
(0.008)\end{array}$ & $\begin{array}{c}0.026^{* * *} \\
(0.008)\end{array}$ & $\begin{array}{c}0.022^{* * *} \\
(0.009)\end{array}$ & $\begin{array}{c}0.023^{* * *} \\
(0.008)\end{array}$ & $\begin{array}{c}0.023^{* * *} \\
(0.008)\end{array}$ \\
\hline lnrate & $\begin{array}{l}-0.007 \\
(0.044)\end{array}$ & $\begin{array}{l}-0.015 \\
(0.044)\end{array}$ & $\begin{array}{c}0.000 \\
(0.044)\end{array}$ & $\begin{array}{l}-0.016 \\
(0.041)\end{array}$ & $\begin{array}{l}-0.022 \\
(0.042)\end{array}$ & $\begin{array}{l}-0.019 \\
(0.043)\end{array}$ \\
\hline lndist & $\begin{array}{c}0.149 \\
(0.183)\end{array}$ & $\begin{array}{l}-0.054 \\
(0.191)\end{array}$ & $\begin{array}{c}0.117 \\
(0.190)\end{array}$ & $\begin{array}{c}0.136 \\
(0.197)\end{array}$ & $\begin{array}{c}0.102 \\
(0.190)\end{array}$ & $\begin{array}{c}0.077 \\
(0.191)\end{array}$ \\
\hline Sector & $\begin{array}{c}-0.548^{* * *} \\
(0.165)\end{array}$ & $\begin{array}{c}-0.582^{\star * *} \\
(0.163)\end{array}$ & $\begin{array}{c}-0.587^{* * *} \\
(0.164)\end{array}$ & $\begin{array}{c}-0.604^{* * *} \\
(0.165)\end{array}$ & $\begin{array}{c}-0.601^{* * *} \\
(0.165)\end{array}$ & $\begin{array}{c}-0.552^{* * *} \\
(0.165)\end{array}$ \\
\hline _cons & $\begin{array}{l}-1.868 \\
(2.917)\end{array}$ & $\begin{array}{l}-0.728 \\
(2.999)\end{array}$ & $\begin{array}{l}-2.518 \\
(3.059)\end{array}$ & $\begin{array}{l}-2.900 \\
(3.150)\end{array}$ & $\begin{array}{l}-3.194 \\
(3.054)\end{array}$ & $\begin{array}{l}-2.399 \\
(3.069)\end{array}$ \\
\hline$N$ & 2352 & 2352 & 2352 & 2352 & 2352 & 2352 \\
\hline Wald $\chi^{2}$ & $55.41^{\star * *}$ & $45.20^{* * *}$ & $46.30^{* * *}$ & $57.77^{* * *}$ & $54.91^{\star * *}$ & $62.00^{* * *}$ \\
\hline Loglikely-hood & -629.931 & -633.921 & -631.179 & -626.243 & -629.606 & -626.941 \\
\hline $\operatorname{LR} \chi^{2}$ & $65.30^{* * *}$ & $57.32^{* * *}$ & $62.80^{* * *}$ & $72.67^{* * *}$ & $65.95^{\star * *}$ & $71.27^{\star * *}$ \\
\hline
\end{tabular}

Note: The values in parentheses are clustering robust standard errors, ${ }^{*},{ }^{* *}$, and ${ }^{* * *}$ indicate it is significant in the significant levels at $10 \%, 5 \%$, and $1 \%$, respectively.

the coefficient of negative system distance itself is significantly negative, and the regression results are consistent with the previous one.

\section{Endogenous Test}

The institutional distance between China and the host country affect the success or failure of foreign direct investment of Chinese enterprises. The success or failure of foreign direct investment of Chinese enterprises also affects the institutional distance through international experience. And this sort of reverse causality causes endogenous bias. Of course, if multinational corporations have 
Table 7. Robustness test with distinction between developed countries and developing.

\begin{tabular}{|c|c|c|c|}
\hline & \multirow{2}{*}{$\begin{array}{c}\text { Developed country } \\
\text { Positive distance }\end{array}$} & \multicolumn{2}{|c|}{ Developing country } \\
\hline & & Positive distance & Negative distance \\
\hline \multirow{2}{*}{ Dist_instiEXP } & -0.619 & -1.121 & $3.771^{*}$ \\
\hline & $(0.756)$ & $(1.095)$ & $(1.947)$ \\
\hline \multirow{2}{*}{ Dist_insti } & $-0.799^{*}$ & -0.200 & $-1.796^{\star * *}$ \\
\hline & $(0.414)$ & $(0.632)$ & $(0.623)$ \\
\hline \multirow{2}{*}{ Experienced } & 1.133 & -0.048 & $2.946^{\star \star}$ \\
\hline & $(0.812)$ & $(0.782)$ & $(1.161)$ \\
\hline \multirow{2}{*}{$\operatorname{lngdp}$} & 0.133 & 0.198 & 0.100 \\
\hline & $(0.117)$ & $(0.136)$ & $(0.217)$ \\
\hline \multirow{2}{*}{ Trade } & $0.008^{*}$ & 0.007 & -0.009 \\
\hline & $(0.004)$ & $(0.008)$ & $(0.008)$ \\
\hline \multirow{2}{*}{ Raw } & 0.009 & $0.013^{*}$ & -0.009 \\
\hline & $(0.007)$ & $(0.007)$ & $(0.007)$ \\
\hline \multirow{2}{*}{ Inter } & $0.027^{\star *}$ & $0.022^{* *}$ & $0.019^{*}$ \\
\hline & $(0.013)$ & $(0.010)$ & $(0.011)$ \\
\hline \multirow{2}{*}{ Tech } & -0.008 & -0.013 & $-0.056^{* * *}$ \\
\hline & $(0.027)$ & $(0.014)$ & $(0.020)$ \\
\hline \multirow{2}{*}{ Ruralp } & $0.062^{\star *}$ & $0.025^{*}$ & 0.012 \\
\hline & $(0.029)$ & $(0.013)$ & $(0.015)$ \\
\hline \multirow{2}{*}{ lnrate } & $-0.284^{*}$ & -0.072 & 0.088 \\
\hline & $(0.157)$ & $(0.064)$ & $(0.074)$ \\
\hline \multirow{2}{*}{ lndist } & $-0.983^{*}$ & 0.247 & 0.542 \\
\hline & $(0.573)$ & $(0.424)$ & $(0.473)$ \\
\hline \multirow{2}{*}{ Sector } & $-0.771^{\star * *}$ & -0.544 & -0.477 \\
\hline & $(0.239)$ & $(0.342)$ & $(0.332)$ \\
\hline \multirow{2}{*}{ _cons } & 4.633 & -6.447 & -6.163 \\
\hline & $(6.271)$ & $(6.756)$ & $(9.360)$ \\
\hline $\mathrm{N}$ & 901 & 710 & 741 \\
\hline Wald $\chi^{2}$ & $44.67^{* * *}$ & $22.81^{* *}$ & $36.22^{* * *}$ \\
\hline Loglikely-hood & -281.589 & -160.745 & -160.847 \\
\hline $\operatorname{LR} \chi^{2}$ & $43.86^{* * *}$ & $19.23^{*}$ & $44.45^{\star * *}$ \\
\hline
\end{tabular}

NNote: The values in parentheses are clustering robust standard errors, ${ }^{*}, * *$ and ${ }^{* *}$ indicate it is significant in the significant levels at $10 \%, 5 \%$, and $1 \%$, respectively.

fewer foreign investment with lower success rate, then they will have less international experience and less impact on institutional distance, and the endogenous problems caused by this will not be serious. The greater the differences between different ethnic groups in cultural traditions and values, the more obvious the institutional differences between different countries [25], the higher failure rates for foreign direct investment in turn. The success or failure of foreign direct investment does not affect the historical and cultural traditions, behavioral habits and value preferences of ethnic groups. With the development of anthropology and biology, the Genetic Distance is used to reflect the root causes of ethnic heterogeneity among different countries and to reveal the historical origins of different ethnic groups. Therefore, gene distance is used in this paper to solve endogeneity problems. When studying the phenomenon of immigration in the world, according to the genetic distances measured by among the 42 major 
nations in the world in the 1980s [26], the scholars used the proportion weighting method of national population to construct the transnational genetic distance [27], which fully reflected the differences of ethnic composition, cultural heterogeneity and immigration status among different countries. The calculation formula is:

$$
\text { gendist }_{i, j}=\sum_{i} \sum_{j} s_{i, p} \cdot s_{j, q} \cdot d_{p q}
$$

Among them, gendist ${ }_{i, j}$ indicates the genetic distance between the country $i$ and $j, s_{i, p}$ indicates the proportion of population of nationality $p$ in the country $i$ to the total population, and $s_{j, q}$ indicates the proportion of nationality $q$ in the country $j$ to the total population, $d_{p q}$ is the genetic distance between the nationality $p$ and $q$.

According to the practice of the scholar [25], a more convincing relative gene distance is taken as a tool variable, and the formula for calculating the relative gene distance is:

$$
\text { Rgendist }_{i, j}=\left[\text { gendist }_{i, U S A}-\text { gendist }_{j, U S A}\right]
$$

Among them, Rgendist ${ }_{i, j}$ is the genetic distance between the country $i$ and country $j$ in comparison with the economic frontier country (United States).

In this paper, the gene distance between the most populous ethnic groups in each country Rgendist_nei_dominan calculated by Nei method is taken as the instrumental variable of institutional distance. The two-step method ${ }^{1}$ of Hilbe [28] adopted by the scholars [29] is used to carry out two-step NB endogenous test. The regression results are shown in Table 8. res_instidt is residual obtained from OLS estimation of the instrumental variables(gene distance) and other control variables by the endogenous variables at the first step. When the residual term estimation coefficient is not significant, the null hypothesis of exogenous variables means that the institutional distance is not rejected. From the two-step NB regression results, it can be seen that the coefficient of the positive system distance residual term passes the $5 \%$ significance test, which means that there is a certain endogeneity problem in the positive institutional distance. And the coefficient of positive institutional distance passes the $1 \%$ significance level test, which is consistent with the previous conclusions. In addition, the coefficient of the residual term of the negative institutional distance is not significant, which may be due to the small number of countries in China's foreign investment negative system, and the low success rate. The less the international experience gained, the smaller the impact on the negative institutional distance. And the endogenous problem caused by it is not serious. According to the F statistic of Table 8, the F value in the first step regression is significantly greater than 10 . ${ }^{1}$ The first step: The OLS estimation of the instrumental variables (gene distance) and other control variables is carried out using the endogenous variables (institutional distance), so as to obtain the corresponding residuals; the second step: Binary regression is carried out using the endogenous variables, the residuals estimated in the first step, and other control variables (excluding instrumental variables), success or failure of foreign direct investment. Only the estimation results of the second step are given in the table, so as to save space. 
Table 8. Endogenous test with gene distance as a tool variable.

\begin{tabular}{|c|c|c|c|c|c|c|}
\hline & \multicolumn{3}{|c|}{ Binary Logit } & \multicolumn{3}{|c|}{ Binary probit } \\
\hline & No direction & $\begin{array}{l}\text { Positive } \\
\text { distance }\end{array}$ & $\begin{array}{l}\text { Negative } \\
\text { distance }\end{array}$ & $\begin{array}{c}\text { No } \\
\text { direction }\end{array}$ & $\begin{array}{l}\text { Positive } \\
\text { distance }\end{array}$ & $\begin{array}{l}\text { Negative } \\
\text { distance }\end{array}$ \\
\hline Dist_insti & $\begin{array}{c}-4.134^{* * *} \\
(1.474)\end{array}$ & $\begin{array}{c}-5.032^{\star * *} \\
(1.695)\end{array}$ & $\begin{array}{c}-2.244 \\
(10.671)\end{array}$ & $\begin{array}{c}-2.004^{* * *} \\
(0.672)\end{array}$ & $\begin{array}{c}-2.553^{\star * *} \\
(0.847)\end{array}$ & $\begin{array}{l}-3.132 \\
(5.193)\end{array}$ \\
\hline Res_instid & $\begin{array}{l}3.455^{\star *} \\
(1.491)\end{array}$ & $\begin{array}{l}4.287^{* *} \\
(1.686)\end{array}$ & $\begin{array}{c}0.619 \\
(10.845)\end{array}$ & $\begin{array}{l}1.657^{* *} \\
(0.679)\end{array}$ & $\begin{array}{l}2.161^{* *} \\
(0.844)\end{array}$ & $\begin{array}{c}2.309 \\
(5.262)\end{array}$ \\
\hline Experienced & $\begin{array}{c}0.185 \\
(0.276)\end{array}$ & $\begin{array}{l}-0.007 \\
(0.305)\end{array}$ & $\begin{array}{c}0.976^{*} \\
(0.555)\end{array}$ & $\begin{array}{c}0.114 \\
(0.136)\end{array}$ & $\begin{array}{c}0.008 \\
(0.158)\end{array}$ & $\begin{array}{l}0.532^{\star} \\
(0.272)\end{array}$ \\
\hline lngdp & $\begin{array}{c}0.303^{\star * *} \\
(0.110)\end{array}$ & $\begin{array}{c}0.398^{\star * *} \\
(0.125)\end{array}$ & $\begin{array}{c}0.114 \\
(0.245)\end{array}$ & $\begin{array}{c}0.145^{\star * *} \\
(0.050)\end{array}$ & $\begin{array}{c}0.207^{\star * *} \\
(0.063)\end{array}$ & $\begin{array}{c}0.021 \\
(0.121)\end{array}$ \\
\hline Trade & $\begin{array}{c}0.011^{* * *} \\
(0.003)\end{array}$ & $\begin{array}{c}0.013^{* * *} \\
(0.003)\end{array}$ & $\begin{array}{l}-0.010 \\
(0.018)\end{array}$ & $\begin{array}{c}0.005^{* * *} \\
(0.001)\end{array}$ & $\begin{array}{c}0.007^{* * *} \\
(0.002)\end{array}$ & $\begin{array}{l}-0.008 \\
(0.009)\end{array}$ \\
\hline Raw & $\begin{array}{l}-0.006 \\
(0.004)\end{array}$ & $\begin{array}{l}0.008^{\star} \\
(0.004)\end{array}$ & $\begin{array}{l}-0.007 \\
(0.033)\end{array}$ & $\begin{array}{l}-0.003 \\
(0.002)\end{array}$ & $\begin{array}{l}0.005^{\star *} \\
(0.002)\end{array}$ & $\begin{array}{c}0.003 \\
(0.016)\end{array}$ \\
\hline Inter & $\begin{array}{c}0.066^{* * *} \\
(0.021)\end{array}$ & $\begin{array}{c}0.104^{* * *} \\
(0.035)\end{array}$ & $\begin{array}{c}0.016 \\
(0.036)\end{array}$ & $\begin{array}{c}0.032^{* * *} \\
(0.010)\end{array}$ & $\begin{array}{c}0.053^{* * *} \\
(0.018)\end{array}$ & $\begin{array}{c}0.002 \\
(0.018)\end{array}$ \\
\hline Tech & $\begin{array}{c}-0.018^{* *} \\
(0.009)\end{array}$ & $\begin{array}{c}0.001 \\
(0.012)\end{array}$ & $\begin{array}{l}-0.064 \\
(0.149)\end{array}$ & $\begin{array}{c}-0.008^{*} \\
(0.005)\end{array}$ & $\begin{array}{c}0.002 \\
(0.006)\end{array}$ & $\begin{array}{l}-0.062 \\
(0.073)\end{array}$ \\
\hline Ruralp & $\begin{array}{c}0.011 \\
(0.009)\end{array}$ & $\begin{array}{l}0.024^{* *} \\
(0.010)\end{array}$ & $\begin{array}{c}0.010 \\
(0.015)\end{array}$ & $\begin{array}{c}0.005 \\
(0.004)\end{array}$ & $\begin{array}{l}0.012^{* *} \\
(0.005)\end{array}$ & $\begin{array}{c}0.002 \\
(0.008)\end{array}$ \\
\hline Rate & $\begin{array}{c}-0.172^{* *} \\
(0.071)\end{array}$ & $\begin{array}{c}-0.251^{* * *} \\
(0.079)\end{array}$ & $\begin{array}{c}0.075 \\
(0.192)\end{array}$ & $\begin{array}{c}-0.088^{* * *} \\
(0.034)\end{array}$ & $\begin{array}{c}-0.129^{* * *} \\
(0.041)\end{array}$ & $\begin{array}{l}-0.002 \\
(0.092)\end{array}$ \\
\hline lndist & $\begin{array}{l}0.631^{\star *} \\
(0.318)\end{array}$ & $\begin{array}{l}0.763^{* *} \\
(0.361)\end{array}$ & $\begin{array}{c}0.468 \\
(0.837)\end{array}$ & $\begin{array}{l}0.303^{\star *} \\
(0.151)\end{array}$ & $\begin{array}{l}0.393^{* *} \\
(0.192)\end{array}$ & $\begin{array}{c}0.064 \\
(0.430)\end{array}$ \\
\hline Sector & $\begin{array}{c}-0.511^{\star * *} \\
(0.168)\end{array}$ & $\begin{array}{c}-0.438^{* *} \\
(0.211)\end{array}$ & $\begin{array}{l}-0.437 \\
(0.502)\end{array}$ & $\begin{array}{c}-0.253^{* * *} \\
(0.083)\end{array}$ & $\begin{array}{c}-0.216^{* *} \\
(0.107)\end{array}$ & $\begin{array}{l}-0.165 \\
(0.251)\end{array}$ \\
\hline _cons & $\begin{array}{c}-10.244^{\star *} \\
(4.650)\end{array}$ & $\begin{array}{c}-16.111^{* * *} \\
(6.068)\end{array}$ & $\begin{array}{c}-3.764 \\
(18.172)\end{array}$ & $\begin{array}{c}-4.653^{\star *} \\
(2.167)\end{array}$ & $\begin{array}{c}-8.234^{\star * \star} \\
(3.168)\end{array}$ & $\begin{array}{c}2.011 \\
(9.354)\end{array}$ \\
\hline Sample size & 2309 & 1595 & 714 & 2309 & 1595 & 714 \\
\hline Wald $\chi^{2}$ & $67.00^{* * *}$ & $65.29^{* * *}$ & $37.10^{* * *}$ & $63.97^{* * *}$ & $64.25^{\star * *}$ & $34.40^{* * *}$ \\
\hline Loglikely-hood & -618.232 & -444.137 & -159.866 & -619.087 & -444.213 & -160.114 \\
\hline $\operatorname{LR} \chi^{2}$ & $76.52^{* * *}$ & $64.97^{\star * *}$ & $37.37^{\star * *}$ & $74.81^{* * *}$ & $64.82^{* * *}$ & $36.88^{* * *}$ \\
\hline F statistic & 405.59 & 336.67 & 32.11 & 405.59 & 336.67 & 32.11 \\
\hline
\end{tabular}

According to the empirical rule, there is no weak tool variable problem. In general, success or failure of Chinese enterprises' foreign investment is obviously constrained by the institutional distance.

\section{Summary and Enlightenment}

The impact of the host country system distance on the success or failure of foreign direct investment by Chinese enterprises is empirically studied in this paper by using the industrial enterprises invested overseas by China from 2005 to 2016 . This article first theoretically analyzes the institutional differences and the possible mechanisms that international experience affects the success or failure of foreign direct investment by Chinese enterprises, and puts forward relevant theoretical assumptions. On the basis of theoretical assumptions, it empirically tests the influence of institutional distance and international experience on the success or failure of foreign direct investment by Chinese enterprises. After test- 
ing, we have the following conclusions: First, the greater the difference in institutional distance (whether positive or negative), the larger the failure of foreign direct investment by Chinese enterprises. That is to say, the institutional distance has a "symmetric effect" on the success or failure of foreign direct investment by Chinese enterprises. Second, international experience, as a "distance bridging" variable, has a regulatory effect of weakening the negative impact of institutional distance on Chinese enterprises' overseas direct investment success rate in the negative institutional distance, but has no regulatory effect in the positive institutional distance. Therefore, the action degree of the institutional distance on the success or failure of foreign direct investment by Chinese enterprises is also affected by the experience of foreign direct investment by Chinese enterprises, but this adjustment is featured by "asymmetric effect". Third, the adjustment of institutional distance to the success or failure of foreign direct investment by Chinese enterprises has industry characteristics. When Chinese enterprises directly invest in "sensitive" industries abroad, the adjustment effect of international experience on the relationship between negative institutional distance and success or failure of investment is less obvious than that in the "non-sensitive" industries. In addition, the sample data of foreign investment by Chinese multinational corporations in the "Belt and Road" countries are examined, which is consistent with the conclusions. Through the above research, we clearly show the impact of the host country system and institutional distance on the success or failure of foreign direct investment by Chinese enterprises. This will help us to understand more deeply the problems that Chinese enterprises may face in transnational operations, and also help Chinese multinational enterprises to go out better and faster.

This article mainly has the following practical enlightenment:

First, in order to promote success rate, we must pay attention to the institutional environment differences between the host country and the country before foreign direct investment by Chinese enterprises. Choices should be made carefully according to the full consideration of the familiarity and adaptability of the local institutional environment.

Second, the effect of institutional distance on the success or failure of foreign direct investment ultimately depends on the previous international investment experience of Chinese companies. Therefore, we must be good at absorbing successful experiences in foreign investment to accelerate the internationalization of emerging multinationals in China. The successful experience of a certain host country should be copied to other similar host countries in the "institutional distance". The successful experiences and failure lessons should be continuously summarized in the experience of foreign direct investment, which will be of great significance to the success of the foreign direct investment.

Third, the kind of industry invested abroad by multinational corporations in China is the key factor in determining whether or not to suffer resistance. Investment in sensitive areas involves geopolitics and national competitiveness. Industries such as communications, energy and high technology are often the 
areas that are relatively sensitive. Chinese multinationals must be cautious when investing in these industries.

Fourth, the bilateral investment agreement is an investment protection mechanism that can compensate for the defect of host country system. When both the quality of the host country system and the distance from the system are poor, bilateral investment agreements reduce the potential risks of the corporate investment and the adverse effects of political conflicts on investment performance. Most of the countries along the "Belt and Road" are developing countries with the poor institutional environment. Our government should pay attention to signing bilateral investment agreements with such countries to make up for their institutional shortcomings, so as to reduce the risk of Chinese enterprises investment in such countries.

Fifth, enterprises should be good at taking advantage of the opportunities for continuous improvement of bilateral political relations between China and the countries along the Belt and Road, and actively maintain and consolidate good diplomatic relations with countries along the "Belt and Road". Political and diplomatic activities such as exchanges of high-level leaders should be strengthened, which can effectively promote Chinese enterprises to "go global" more successfully.

Sixth, enterprises must improve their own ownership advantages. The unique resources such as management, technology, and patents should be acquired at most to strengthen our competitiveness and improve our ability to withstand foreign investment risks. At the same time, the efficiency of foreign direct investment should be truly improved by actively learning the experience and lessons of foreign investment blocking. In addition, the management of institutional risks in the host country should be strengthened, and the dynamic changes of various institutional factors should be grasped, so as to flexibly adjust and optimize the existing OFDI strategy.

\section{Conflicts of Interest}

The author declares no conflicts of interest regarding the publication of this paper.

\section{References}

[1] North, D.C. (1990) Institutions, Institutional Change and Economic Performance. Cambridge University Press, Cambridge. https://doi.org/10.1017/CBO9780511808678

[2] Blonigen, B.A.A. (2005) Review of the Empirical Literature on FDI Determinants. Atlantic Economic Journal, 33, 383-403. https://doi.org/10.1007/s11293-005-2868-9

[3] Daniele, V. and Marani, U. (2008) Do Institutions Matter for FDI? A Comparative Analysis for the MENA Countries. MPRA Paper No. 2426.

[4] Yan, C.L. and Zou, C. (2013) The Host Country's System Quality and Institutional Distance and the Location of China's Foreign Direct Investment. Contemporary Finance and Economics, No. 7, 100-110. 
[5] Chen, C.S., Liu, X.D. and Yi, C.J. (2017) The Influence of Overseas Chinese Business Network and Host Country System Environment on China's OFDI-The Perspective Based on "One Belt and One Road". Journal of Fujian Normal University (Philosophy and Social Sciences Edition), No. 1, 79-86.

[6] Buckley, P.J., et al. (2007) The Determinants of Chinese Out-Ward Foreign Direct Investment. Journal of International Business Studies, 38, 499-518. https://doi.org/10.1057/palgrave.jibs.8400277

[7] Kolstad, I. and Wiig, A. (2012) What Determines Chinese Out-Ward FDI? Journal of World Business, 47, 26-34. https://doi.org/10.1016/j.jwb.2010.10.017

[8] Li, X.M. and Li, C.M. (2016) Institutional Risks of Countries along the "Belt and Road" and the Economic Logic of Chinese Enterprises to "Go Out". Contemporary Economic Management, No. 38, 8-14.

[9] Kostova, T. (1999) Transnational Transfer of Strategic Organizational Practices: A Contextual Perspective. Academy of Management Review, 24, 308-324. https://doi.org/10.5465/amr.1999.1893938

[10] Habib, M. and Zurawick, L. (2002) Corruption and Foreign Direct Investment. Journal of International business Studies, 33, 291-307. https://doi.org/10.1057/palgrave.jibs.8491017

[11] Bénassy-Quéré, A., Coupet, M. and Mayer, T. (2007) Institutional Determinants of Foreign Direct Investment. World Economy, 29, 38-53. https://doi.org/10.1111/j.1467-9701.2007.01022.x

[12] Yan, D.Y. (2011) Research on the Institutional Distance, International Experience and the Success or Failure of Chinese Enterprises' Overseas Merger and Acquisition. Nankai Economic Research, No. 5, 75-97.

[13] Guo, S.W. and Huang, H.M. (2010) The Influence of Institutional Distance on China's External FDI-An Empirical Study Based on Dynamic Panel Model. International Economics and Trade Research, No. 11, 21-26.

[14] Du, J. and Song, Y.G. (2014) Institutional Distance, Factor Endowment and Chinese OFDI Location Choice Preference-An Empirical Study Based on Dynamic Panel Data Model. World Economy Study, No. 12, 47-52.

[15] Jiang, G.H. and Jiang, D.C. (2012) Is the Host Country System Important-For China's Investment in Developing Countries? Management World, No. 11, 45-56.

[16] Xu, D. and Shenkar, O. (2002) Institutional Distance and the Multinational Enterprise. The Academy of Management Review, 27, 608-618. https://doi.org/10.2307/4134406

[17] Li, X. and Wan, N. (2016) The Legitimacy Threshold of Multinational Enterprises: The Perspective of Institutional Distance. Management World, No. 5, 184-185.

[18] Hymer, S.H. (1976) The International Operations of National Firms: A Study of Direct Foreign Investment. Doctoral Dissertation, Massachusetts Institute of Technology, Cambridge.

[19] Sepulveda, M., Angel, J. and Rodriguez, D. (2014) Geographical and Industrial Spillovers in Entry Decisions across Export Markets. MPRA Paper No. 53249.

[20] Delios, A. and Henisz, W.J. (2003) Political Hazards, Experience, and Sequential Entry Strategies: The International Expansion of Japanese Firms, 1980-1998. Strategic Management Journal, 24, 1153-1164. https://doi.org/10.1002/smj.355

[21] Pogrebnyakov, N. and Mait-land, C.F. (2001) Institutional Distance and the Internationalization Process: The Case of Mobile Operators. Journal of International Management, 17, 68-82. https://doi.org/10.1016/j.intman.2010.12.003 
[22] Hernandez, V. and Nieto, M.J. (2015) The Effect of the Magnitude and Direction of Institutional Distance on the Choice of International Entry Modes. Journal of World Business, 50, 122-132. https://doi.org/10.1016/j.jwb.2014.02.002

[23] $\mathrm{Xu}, \mathrm{D}$., et al. (2004) The Effect of Regulative and Normative Distance on MNE Ownership and Expatriate Strategies. Mir Management International Review, 44, 285-307.

[24] Yang, L., Liu, X. and Zhang, J. (2016) How Bilateral Political Relations Affect Foreign Direct Investment-Based on the Perspective of Binary Margin and Investment Success and Failure. China Industrial Economy, No. 11, 56-72.

[25] Huang, X., Shu, Y. and Yu, M. (2013) Institutional Distance and Cross-Border Income Gap. Economic Research, No. 9, 4-16.

[26] Cavalli-Sforza, L.L., Menozzi, P. and Piazza, A. (1994) The History and Geography of Human Genes. Princeton University Press, Princeton.

[27] Spolaore, E. and Wacziarg, R. (2009) The Diffusion of Development. Quarterly Journal of Economics, 124, 469-529. https://doi.org/10.1162/qjec.2009.124.2.469

[28] Hilbe, J.M. (2011) Negative Binomial Regression. 2nd Edition, Cambridge University Press, Cambridge. https://doi.org/10.1017/CBO9780511973420

[29] Zhou, H. and Zheng, Y. (2015) The Impact of Environmental Regulation on Industrial Transfer-Evidence from the Location of New Manufacturing Enterprises. Southern Economy, No. 4, 12-26. 